\title{
AOR
}

Selected Papers of \#AolR2020:

The $21^{\text {st }}$ Annual Conference of the

Association of Internet Researchers

Virtual Event / 27-31 October 2020

\section{TABOO OR NOT TABOO: (IN)VISIBILITIES OF DEATH, DYING AND BEREAVEMENT}

\author{
Ylva Hård af Segerstad (Chair) \\ University of Gothenburg, Sweden \\ Jo Bell \\ University of Hull, UK \\ Korina Giaxoglou \\ Open University, UK \\ Stacey Pitsillides \\ Northumbria University, UK \\ Daphna Yeshua-Katz \\ Ben Gurion University of the Negev, Israel \\ Kathleen Cumiskey (Respondent) \\ College of Staten Island, US \\ Larissa Hjorth (Respondent) \\ RMIT University, Australia
}

\section{Introductory statement}

The notion that 'death is a taboo' pervades private, public and academic discourses around death, dying and bereavement in contemporary Western societies. The rise of digital media within the last decades further complicates the appreciation of the stance that death is a taboo, given the increased opportunities afforded in social media environments for embracing death, fostering new intimacies with strangers and semistrangers but also for turning death into a spectacle (Jakobsen, 2016). The study of death-related practices online and the tensions they raise has rapidly been growing in the interdisciplinary field of Death online studies, and the members of this panel have all been contributing to this development (e.g. Christensen \& Sandvik, 2014; Hård af 
Segerstad \& Kasperowski, 2015; Giaxoglou et al., 2017; Giaxoglou et al., 2018). However, in this field there is a need for developing shared conceptual and analytical frameworks and ensure methodological and theoretical robustness in line with developments in the study of social media communication.

In many ways, reflections on death crystallise core norms, values, tensions and beliefs of social systems and, on a larger scale, of contemporary Western societies. The study of death and communication, thus, needs to address more thoroughly the sociocultural processes around tabooisation calling attention to communicative practices, narrative and emotional ideologies, technological affordances, cultural values, identity performances, social bonding and coping mechanisms, legal matters and ethics, and technological embeddedness. There is a need to synthesize insights from death sociology and interdisciplinary death online studies in order to shape an agenda for an integrated study of the offline and the online that can capture continuities and shifts in death-related practices (see also Borgstrom and Ellis, 2017).

\section{Organization of the panel}

The panel consists of three papers presented by five interdisciplinary scholars from Denmark, Sweden, Israel and the UK. Focusing on the (in)visibilities of death, dying and bereavement across contexts - online and offline - the papers critically revisit the 'death is taboo' thesis by investigating the particular conditions under which death, dying and bereavement are talked about, storied, and made socially visible and the ways in which technology plays a vital part in coping with mortality.

The paper by Ylva Hård af Segerstad, Jo Bell and Daphna Yeshua-Katz, "DESIGNED TO DIE: ON THE EPHEMERALITY AND OBSOLESCENCE OF DIGITAL REMAINS" seeks to contribute to a better understanding of the (post)human encounter with death by exploring how bereaved individuals engage with the digital remains of their deceased loved ones, and how both the digital devices themselves and their digital content constitute potential tools for coping with loss.

The paper by Korina Giaxoglou, "LIFE, DEATH AND TABOO: TECHNOLOGICAL FUTURES OF CURIOSITY AND CRITIQUE” explores how practice research that works with cultural partners, like libraries, can help the public to re-imagine the future of death, providing new spaces to reflect on the role of technology in people's lives and losses. It investigates whether death can be shifted from a taboo or private experience to an expression of self/ post-self or communities and how design futures may help people to explore an ever changing relationship between technology and the body.

The paper by Stacey Pitsillides, "SHARING THE EMOTIONAL SELF: TELLABILITIES OF DEATH, DYING AND GRIEF ONLINE", investigates the "darker side" of tellability, focusing on practices of sharing of the emotional self in online contexts in relation to the positions they make available for networked audiences, which relates to experiences of death, dying and grief. 
Following the paper presentations, our two respondents Kathleen Cumiskey and Larissa Hjorth - both with extensive expertise in the field and long-time prominent members of AolR - will offer comments before opening the panel to discussion with the audience.

\section{References}

Ariès, P. (1974) Western attitudes toward death: from the middle ages to the present. Baltimore and London: The Johns Hopkins University Press.

Borgstrom, Erica and Ellis, Julie (2017). Introduction: Researching Death, Dying and Bereavement. Mortality, 22(2) pp. 93-104.

Christensen, Dorthe Reflsund and Kjetil Sandvik (2014) Mediating and Remediating Death: studies in death, materiality and the origin of time. Farnham, Surrey: Ashgate.

Giaxoglou, Korina, Döveling, Katrin and Pitsillides, Stacey (2017) Networked Emotions: Interdisciplinary Perspectives on Sharing Loss Online. Journal of Broadcasting \& Electronic Media, 61 (1), pp. 1-10.

Giaxoglou, Korina and Döveling, Katrin (2018) Mediatization of Emotion on Social Media: Forms and Norms in Digital Mourning Practices. Social Media + Society 4 (1), pp. 1-4.

Hård af Segerstad, Y., \& Kasperowski, D. (2015). A community for grieving: Affordances of social media for support of bereaved parents. New Review of Hypermedia and Multimedia, 21(1-2), 25-41.

Jakobsen, Michael Hviid (2016) "Spectacular Death" - Proposing a New Fifth Phase to Philippe Aries' s Admirable History of Death. Humanities 5 (2): 19. 


\title{
AOR
}

Selected Papers of \#AolR2020:

The $21^{\text {st }}$ Annual Conference of the

Association of Internet Researchers

Virtual Event / 27-31 October 2020

\section{DESIGNED TO DIE: ON THE EPHEMERALITY AND OBSOLESCENCE OF DIGITAL REMAINS}

\author{
Ylva Hård af Segerstad \\ University of Gothenburg, Sweden \\ Jo Bell \\ University of Hull, UK \\ Daphna Yeshua-Katz \\ Ben Gurion University of the Negev, Israel
}

\section{Introduction}

Our lives are increasingly saturated by digital devices. Mobile phones, laptops and tablets mediate our everyday engagement through social media and digital services. Taking a post-humanist approach, mobile phones may even be regarded as "prostheses", transcending the limitations of the physical human form by extending our human senses and abilities allowing for telepresence and remote communication (Haraway, 2007). The devices themselves contain and connect to what can be described as the digital remains we leave behind when we die. These remains can be seen to contain the "essence" of the deceased (writings, online behaviour, photos, videos, etc.) as a result of the increasing ubiquity of digital media in our lives. In addition, the digital remains left behind by the dead may function as transitional objects (Mowlabocus, 2016), helping bereaved individuals to adapt to a reality without the lost loved ones and to continue bonds (Klass, Silverman, \& Nickman, 1996; Walsh \& McGoldrick, 2004).

For much of the 20th century to maintain continuing bonds with deceased loved ones was regarded an indicator of pathology in grief. With the Continuing Bonds theory, Klass et al. (1996) introduced a shift among bereavement theorists away from the emphasis on detachment and toward a willingness to include maintained connections with the deceased as a natural part of the bereavement process. Walter (1996) proposed a new model of grief that allows the continued presence of the dead within people's lives and continuous conversations with and about them. Building on Katherine Hayles' ideas of the posthuman, Pitsillides and Jefferies (2013) considered how our digital remains may take the role of legacy continuing on and engaging with the living through the construct of 'posthumanism'. They argued that a posthumanist 
approach makes room for new conceptions of thinking about the role of the dead in society, including "the agency they still have through: memory, things they leave behind, social networks, spaces, paths: digital or otherwise."

However, as noted by Walter (2015), digital remains are ephemeral. Both in terms of hardware and digital content, obsolescence is built in by design. So, like our physical selves these digital remains are mortal, they are designed to 'die'.

Based on interview and survey data gathered from the contexts of Israel, the UK and Sweden, we explore how bereaved individuals engage with the digital remains of their deceased loved ones and how both the digital devices themselves and their content constitute potential tools for coping with loss. We construct our analysis around two themes: Firstly, our participants invested efforts in maintaining bonds with their deceased loved ones by continuing to engage with the left-behind devices and content. Secondly, the ephemeral nature of these digital remains, highlights their fragility as the technology which sustains them eventually will become obsolete.

\section{Post-humanist perspectives on continuing bonds}

Here we refer to the 'essence' (spiritual, physical, emotional, psychological, social and personal) of the deceased person embodied within the digital device. We trace the idea of the technological device, including its software, data and applications, being more or less an extension of the body and the person in the post-humanist sense. Digital remains seem to function as transitional objects offering the bereaved means to continue bonds; and as tools for making sense of the loss.

Our study examines the evolution of the deceased's personhood on social media and other digital platforms in the wake of a suicide. The work highlights the preservation of devices and use of digital content as means for continuing bonds. One participant kept the phone and voice message of her deceased son. She felt it contained the 'essence' of him, preserved in the digital device. Other participants deliberately kept phone numbers so they could maintain contact and send messages to the dead. They also sent private messages to the deceased via their 'in-life' Facebook accounts which they kept on maintaining. Another talked about ways in which the computer belonging to her deceased son embodied his 'spirit.' The physical proximity of his mobile phone meant that wherever she was she could 'conjure up' his digital remains (photographs, videos, conversations, likes and dislikes), momentarily bringing him back to life at the click of a button.

Some of the bereaved parents took comfort in using the Spotify lists created by their deceased young adult child in their everyday lives. They described the ways in which they felt how this connected them to their deceased child's state of mind, highlighting how the Spotify lists acts as a conduit to the dead in the posthuman sense.

\section{Ephemerality and obsolescence}

A widow in the study continued to charge the mobile phone that belonged to her deceased husband, Rami. She payed the phone bill and carried the device around with her. She also used it to post on his Facebook profile, which made it look like he 
continued to post, activating a response from the dead. In life, he and his family used a joint WhatsApp group to communicate. The family continued to use the group platform after his death and included him in the messages as before. However, one morning there was a new message in the group which freaked the family members out: "Rami left the group." The family gathered to find out how on earth their dead husband, father and grandpa could have left the group at this point. The app displayed the following message: "Please update your WhatsApp app." Apparently a missing application update on the device Rami left behind lead to his sudden digital departure. And so eventually, as a result of design and function (built-in obsolescence), the technological apparatus that sustained his digital existence was superseded with new iterations resulting in his digital demise.

In our discussion, we focus on the ways digital affordances - the multidimensional relationship between the object, or technology, and the user - enable continuing bonds between the living and the dead. We examine what is being preserved, how long it is preserved for, how it changes over time, what happens when it 'dies', and what this means for 'continuing bonds'. In doing so we seek to contribute to a better understanding of the (post)human encounter with death.

\section{References}

Haraway, D. (2007). A Cyborg Manifesto: Science, Technology, and SocialistFeminism in the Late 20th Century. In The International Handbook of Virtual Learning Environments (pp. 117-158).

Klass, D., Silverman, P. R., \& Nickman, S. L. (Eds.). (1996). Series in death education, aging, and health care. Continuing bonds: New understandings of grief. Taylor \& Francis.

Mowlabocus, S. (2016). The "mastery" of the swipe: Smartphones, transitional objects and interstitial time. First Monday, 21(10).

Pitsillides, S., \& Jefferies, J. (2013). Narrating the Digital: The Evolving Memento Mori. In Digital Legacy and Interaction (pp. 83-99). Springer, Cham.

Walsh, F., \& McGoldrick, M. (Eds.). (2004). Living beyond loss: Death in the family, 2nd ed. Living beyond Loss: Death in the Family, 2nd Ed., pp. xxv, 443-xxv, 443. New York, NY, US: W W Norton \& Co.

Walter, T. (1996). A new model of grief: Bereavement and biography. Mortality, 1(1), 7-25.

Walter, T. (2015). Communication media and the dead: from the Stone Age to Facebook. Mortality, 20(3), 215-232. 


\section{AOR}

Selected Papers of \#AolR2020:

The $21^{\text {st }}$ Annual Conference of the

Association of Internet Researchers

Virtual Event / 27-31 October 2020

\section{SHARING THE EMOTIONAL SELF: TELLABILITIES OF DEATH, DYING AND GRIEF ONLINE}

Korina Giaxoglou,

The Open University, UK

Death is often included among the so-called 'taboo' topics, alongside topics relating to sex and moral indignation. Sociolinguist William Labov (2013), for example, argues that these topics are of limited tellability, i.e. they are less likely to be considered as worthy of being reported or storied in front of - or for the sake of - an audience. And yet, tellability (also sometimes known as reportability or narratability) is not an absolute property of topics. It is, rather, shaped by - as much as it shapes specific contexts of talk (or text), the participants involved, and their socially and culturally-informed views of what incidents, topics, stories and "points" are deemed to be appropriate for reporting (Baroni, 2011). As Ochs and Capps (2001) have argued, tellability constitutes a gradient dimension of narrative discourse amenable to empirical study. In cases of the telling of experiences, which exceed the maximum threshold for tellability, due to the sense that they are too personal, too embarrassing, or obscene to be shared with others, the "darker side" of tellability is brought to the fore (Norrick, 2005, p. 323).

This paper investigates this "darker side" of tellability, focusing on the sharing of the emotional self with a focus on experiences of death, dying and grief. As Semino et al. (2012) note, death can often be felt to be untellable, even if it can be included among the experiences which are deemed to be reportable. The starting point, here, is that the (un)tellability of death, dying and grief is socially constructed in language; it is, in other words, inflected by narrative and discourse regimes, as for instance ideas - or struggles, in some cases - about what counts as a 'good' death, a 'good' dying or a 'good' grief. Negotiations of (un) tellability are, thus, located within webs of visibility, power and politics (Carpentier and van Brussel, 2012; Cromby et al., 2014), which tend to change over time (Semino et al. 2012). In an age where interaction is largely mediated by digital technologies of communication, views about the reportability and (un)tellability of death, dying and grief are diversifying and changing at a fast pace in association with emerging norms and conditions of sharing on social media, which are worthy of empirical study (see Giaxoglou, 2020).

Taking a discourse-narrative approach, this paper examines the (un)tellabilities of death, dying, and grief in different online contexts, arguing that it is important (i) to 
study tellability in the plural (i.e. tellabilities), in order to avoid essentializing it as an inherent property (or not) of specific topics and (ii) to extend the study of tellabilities to shareability-ies online. The paper presents key findings from a study of selected social media events through which death, dying and grief is marked with and for networked audiences, accompanied by a consideration of social media users' own views about the drivers and meaning of such practices. The analysis focuses on instances of negotiations of the two-sided notion of tellability (i.e. upper and lower, see Norrick, 2005) and shows the different ways in which tellers orient to and negotiate the upper boundary of tellability, when they talk about or share posts relating to death, dying and grief. More specifically, I look at how tellers signal to their audiences that they are approaching a threshold of tellability and examine when (and how) they move on to breach it in the pursuit of other interactional, relational and identity purposes.

The analysis of tellabilities in context is based on the empirical framework of affective positioning in story-telling (Giaxoglou, 2020). Affective positioning refers to the modulations of proximity or distance to (i) the death event and the dead, (ii) the (known and unknown) networked audiences, and (iii) the emotional self and it is inextricably connected to the situated emplotment of death, dying and grief.

The aim of this paper is to provide empirical insights into connections between attitudes to death, dying and grief link and norms of sharing the emotional self within broader technosocial (re)configurations of the domain of visibility of topics, experiences, and emotions, often thought to be 'private', 'hidden' or even 'taboo'. This paper builds on the body of research on the changing attitudes to the management of death (Ariès, 1974; Jacobsen, 2016) and its remediation online (Refslund Christensen and Sandvik, 2014) and contributes to the empirical investigation of the popular thesis that 'death is taboo'.

\section{References}

Ariès, P. (1974) Western attitudes toward death: from the middle ages to the present. Baltimore and London: The Johns Hopkins University Press.

Baroni, R. (2011) Tellability. In the Living Handbook of Narratology. Available at: https://www.Ihn.uni-hamburg.de/node/11.html.Accessed: 24 Feb. 2020.

Giaxoglou, K. (2020) A narrative approach to social media mourning: small stories and affective positioning. London and New York: Routledge.

Jacobsen, M.H. (2016) "Spectacular Death - Proposing a New Fifth Phase to Philippe

Ariès's Admirable History of Death". Humanities 5 (2), 19: 1-20.

Labov, W. (2013) The Language of Life and Death: The Transformation of Experience in Oral Narrative. Cambridge: Cambridge University Press.

Norrick, N.R. (2005) The dark side of tellability. Narrative Inquiry 15 (2): 323-343. 
Ochs, E. and L. Capps (2002) Living Narrative: Creating Lives in Everyday Storytelling. Cambridge, MA: Harvard University press.

Refslund Christensen, D. and K. Sandvik (2014) (eds.) Mediating and Remediating Death - Studies in Materiality and the Origin of Time. London and New York: Routledge.

Semino, E., Z. Demjen, and V. Koller (2014) '“Good' and 'bad' deaths: Narratives and professional identities in interviews with hospice managers". Discourse Studies 16 (5): 667-685. 


\title{
AOR
}

Selected Papers of \#AolR2020:

The $21^{\text {st }}$ Annual Conference of the

Association of Internet Researchers

Virtual Event / 27-31 October 2020

\section{LIFE, DEATH AND TABOO: TECHNOLOGICAL FUTURES OF CURIOSITY AND CRITIQUE}

\author{
Stacey Pitsillides \\ Northumbria University, UK
}

The future of death is entangled in uncertainty. With technologies and human nature shifting in ways that are only just becoming apparent to us. Our legacies are now blended sites of on and offline identities, that come with questions of privacy, ownership and control that are continuously being redefined both socially and legally (Edwards \& Harbinja, 2013). Online environments also provide digital versions of honouring the dead (Gotved, 2014) that stimulate ethical and practical questions about the nature of death and dying. Whilst our relationships are being redefined through the pervasiveness of talking to the dead on social media (Kasket, 2019). Beyond this, transhumanist companies like LifeNaut blend the human and nonhuman (through robotics) allowing for critical reflection points on notions of immortality. In response to these trends technologies for dealing with human remains and memories sensitively, are developing at such a pace that many things thought to be fictional like: enclosing your entire digital life into a physical object; splicing your DNA with a tree; and human composting are not only being researched but have become products that are currently passing through policy.

The UK is an increasingly diverse society with complex-beliefs and multipleidentities, which makes it a good candidate to explore how technology is shifting public perceptions of death and dying. Ecological concerns (Rumble et al, 2014) and cultural shifts (Davies, 2017) are also driving us towards new forms of dispersing human remains at the end of life, while the funeral industry is being placed under a tremendous amount of scrutiny around the cost and transparency of services, following the UK government's ongoing investigation of the sector. This paper will explore how practice research that works with cultural partners, like libraries, can help the public to re-imagine the future of death, providing new spaces to reflect on the role of technology in people's lives and losses. It will also discuss some participants reflections on a series of six installations called Love After Death. These installations question how future technologies and aesthetics augment our relationship to end-of-life planning - aiming to build critical conversations around these themes. 
As a practice, design is well positioned to critically challenge whether we can move beyond the death-denial thesis (Tradii and Robert, 2019). Lyn Loftland's text The Craft of Dying: The Modern Face of Death (1978) explores the roots of anti deathdenial movements. She states that these movements often champion 'talking about death' and being 'death positive'. However as death and dying can be difficult and sensitive topics to discuss and technological perspectives may reveal a range of other social questions e.g. privacy/ ownership of data, the contemporary focus on discussion as the primary mode of engagement may not be enough to explore the boundaries of our perceptions and taboos. Additionally, talking about death does not necessarily prompt the discovery of new rituals and it may not engage the most diverse audiences (Baldwin, 2017).

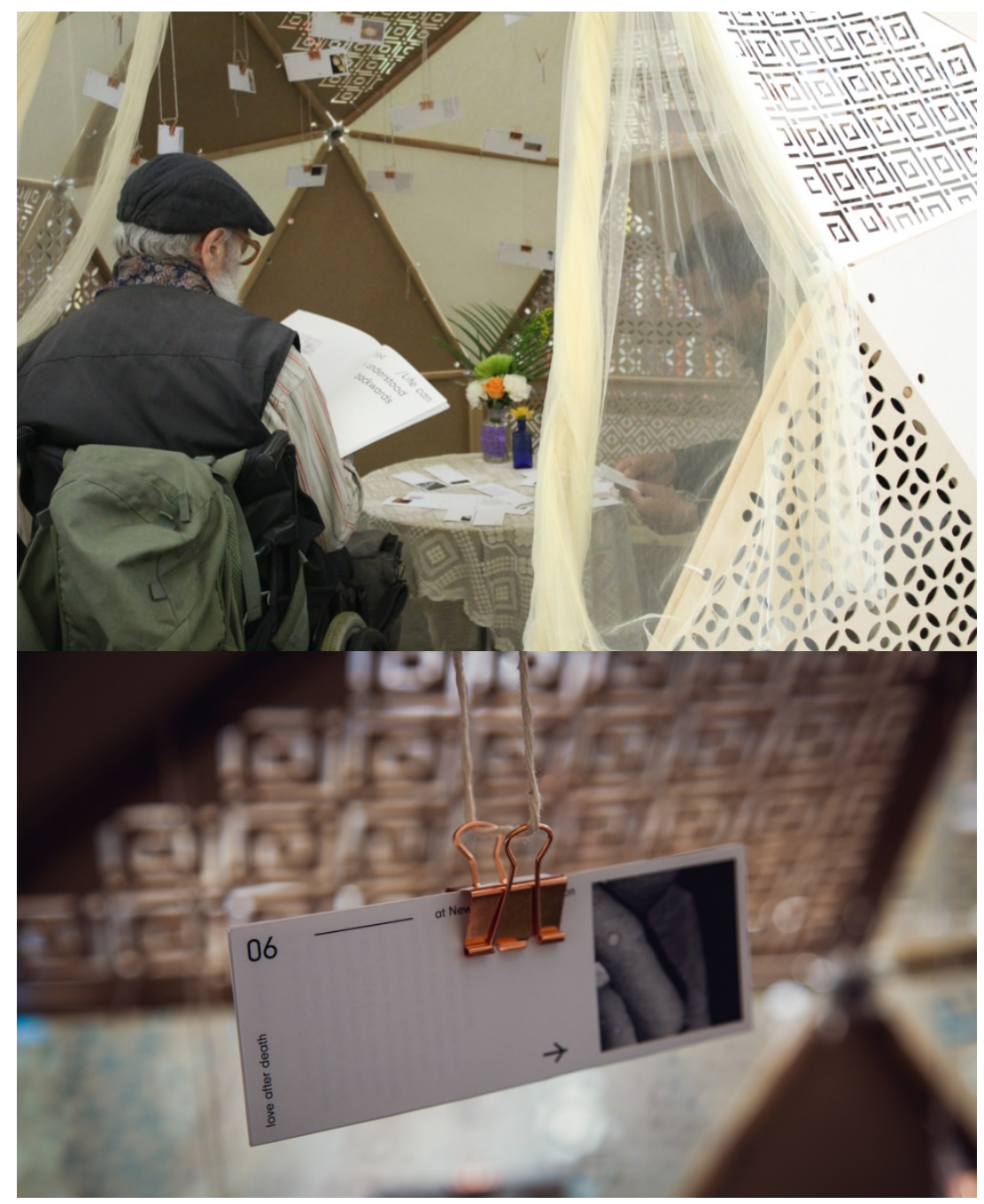

Figure 1: Love After Death installed at Redbridge Library (Day of the Dead) and Newcastle City Library (Festival of Social Science) (2019)

Love After Death tackles death literacy by working with libraries in London, Yorkshire and Newcastle (UK) expanding their role in the community as a safe and trusted spaces. It introduces people to planning end of life wishes using artistic research methods and playful diegetic prototypes (Kirby, 2010) that position potential futures 
(DiSalvo, 2009: 58) as options to be chosen. For both researchers and library staff this is explored through live methods and public testing - where design installations are used to activate critical questions around the public's engagement with death and dying.

Over the six installations, participants stated that it has helped them to think critically about their own end of life choices. Alongside introducing them to new choices and controversial topics like radical life extension that may be available in the future. Many participants reflected on their religious and cultural identity and how the different options spoke to people of $2^{\text {nd }}$ and $3^{\text {rd }}$ generation British citizens with a migration background. A sample of 10 participants were interviewed in the first phase (2nd installation), which took place at Redbridge Library, London (2018) during Dying Matters Week UK. 7 males 3 females were interviewed, ages ranging from 20 s to 60 s with a range of ethnicities and religious identities:

"I think it's important ... to learn more about the funerals and how you organise what options there are now the technical is advancing, new ideas, creative... something to share with the family and community" - ParticpantM4 (Tamil Sri Lankan, Hindu)

"Firstly I was so scared but actually after talking to them I'm very positive, I gained knowledge that when you die your body doesn't die, there are so many uses after the death of your body and life and of course technology" ParticpantF9 (Hindu)

"I am interested in how technology may be able to preserve people's stories so future generations will be able to access things like family history and life experience as well as marking the loss of their loved ones and bereavement" ParticpantM10 (Anglican Priest)

"I've got a vested interest, I'm a funeral director but ... what I found interesting was one of their questions whether you would like to recycle the energy from your cremation and when you can give it to a social cause which I thinks a really really good idea at the moment, the only donation from cremation is you can donate any metals that's left... so why couldn't there be another box saying would you like to recycle the energy from cremation." ParticpantM11 (Atheist)

From these excerpts it is clear that technology played a key role in what they took away from this installation. By making trends online and new forms of disposal of the dead tangible choices, it helped people to gain more consciousness about their agency at the end of life and the role funeral directors play in this. These interviews begin to investigate whether death can be shifted from a taboo or private experience to an expression of self/ post-self or communities and how design futures may help people to explore an ever changing relationship between technology and the body. 


\section{References}

Davies, D. (2017). Death, ritual and belief: The rhetoric of funerary rites. Bloomsbury Publishing.

DiSalvo, C. (2009). Design and the Construction of Publics. Design issues, 25(1), 48-63.

Edwards, L., \& Harbinja, E. (2013). "What Happens to My Facebook Profile When I Die?": Legal Issues Around Transmission of Digital Assets on Death. In Digital legacy and interaction (pp. 115-144). Springer, Cham.

Gotved, S., (2014). Research Review: Death Online-Alive and Kicking!. Thanatos.

Kasket, E., (2019). All The Ghosts In The Machine. London: ROBINSON.

Kirby, D. (2010). The future is now: Diegetic prototypes and the role of popular films in generating real-world technological development. Social Studies of Science, $40(1)$, 41-70.

Lofland, L. H. (2019) [1978]. The craft of dying: The modern face of death. MIT Press.

Rumble, H., Troyer, J., Walter, T., \& Woodthorpe, K. (2014). Disposal or dispersal? Environmentalism and final treatment of the British dead. Mortality, 19(3), 243-260.

Tradii, L., \& Robert, M. (2019). Do we deny death? II. Critiques of the death-denial th 